\title{
The meanings of work and masculinity: a study with military police officers
}

\author{
Os sentidos do trabalho e masculinidade: um estudo com policiais militares \\ Los significados del trabajo y la masculinidad: un estudio con policías militares
}

Received: 11/01/2021 | Reviewed: 11/09/2021 | Accept: 10/11/2021| Published: 11/20/2021

\author{
Samuel Carminatti \\ ORCID: https://orcid.org/0000-0001-5431-0838 \\ IMED Business School, Brazil \\ E-mail: carminatti.samuel@gmail.com \\ Shalimar Gallon \\ ORCID: https://orcid.org/0000-0002-8830-4433 \\ IMED Business School, Brazil \\ E-mail: shalimargallon@gmail.com \\ Carlos Costa \\ ORCID: https://orcid.org/0000-0003-0402-3763 \\ IMED Business School, Brazil \\ E-mail: carlos.costa1@gmail.com \\ Vitor Francisco Dalla Corte \\ ORCID: https://orcid.org/0000-0002-4620-0601 \\ IMED Business School, Brazil \\ E-mail: vitordallacorte@gmail.com
}

\begin{abstract}
The research aims analyze the meanings of work for military police officers and the meanings' associations with the concepts of masculinity. Based on quantitative research, three hundred Brazilian military police responded to a structured questionnaire classified on a five-point Likert scale. Data was collected in person and online using Qualtrics software, then tabulated and organized using JASP v software. 0.14.1. The results shows that military police officers perceive recognition of their work, based on autonomy. Moreover, they see their work as strongly related to moral rectitude and social utility. They associate the meanings of their work with issues of dignity and respect for human rights and the feeling of generating positive impacts and results for society. However, this also results in a homogenization of the individual within the organization: they cannot show emotions, must be heterosexual, withstand provocations, be conservative in terms of the values of the institution and the profession.
\end{abstract}

Keywords: Meanings of work; Masculinities; Military police; Human resources management.

\section{Resumo}

O objetivo do estudo foi analisar os sentidos do trabalho para policiais militares e suas associações com os conceitos de masculinidade. Com base em uma pesquisa quantitativa, trezentos policiais militares brasileiros responderam a um questionário estruturado classificado em uma escala Likert de cinco pontos. Os dados foram coletados pessoalmente e online usando o software Qualtrics, então tabulados e organizados usando o software JASP v. 0.14.1. Os resultados mostram que os policiais militares percebem reconhecimento em seu trabalho, a partir da autonomia. Eles veem, ainda, o seu trabalho com forte relação à retidão moral e à utilidade social, o que representa que os sentidos do trabalho estão associados a questões de dignidade e respeito aos direitos humanos e ao sentimento de gerar impactos e resultados para a sociedade. No entanto, os resultados mostram para uma homogeneização do indivíduo na organização em contexto: não pode demonstrar emoções, tem que ser heterossexual, aguentar provocações, ser conservador aos valores da instituição e da profissão.

Palavras-chave: Sentidos do trabalho; Masculinidades; Polícia militar; Gestão de pessoas.

\section{Resumen}

El objetivo del estudio fue analizar los significados del trabajo para los policías militares y sus asociaciones con los conceptos de masculinidad. Sobre la base de una encuesta cuantitativa, trescientos policías militares brasileños respondieron a un cuestionario estructurado calificado en una escala Likert de cinco puntos. Los datos se recopilaron en persona y en línea utilizando el software Qualtrics, luego se tabularon y organizaron utilizando el software JASP v. 0.14.1. Los resultados muestran que los policías militares perciben el reconocimiento en su trabajo, basado en la autonomía. También ven su trabajo fuertemente relacionado con la rectitud moral y la utilidad social, lo que significa que los significados del trabajo están asociados a cuestiones de dignidad y respeto a los derechos humanos y al sentimiento de generar impactos y resultados para la sociedad. Sin embargo, los resultados muestran una homogeneización del individuo en la organización en contexto: no puede mostrar emociones, tiene que ser heterosexual, soportar provocaciones, ser conservador con los valores de la institución y la profesión.

Palabras clave: Significados del trabajo; Masculinidades; Policia militar; Gestión de personal. 


\section{Introduction}

Work is considered a reason for man's insertion into society, as it has a decisive place in the life of each individual (Hulin, 2014; Primaria et al., 2015). It represents an important contemporary value that also influences people's behavior and satisfaction (Spinelli-de-Sá and Lemos, 2018). Identification with work allows for workers' engagement and commitment (Rodrigues et al., 2016). The meaning of work allows people to identify with the tasks they perform, to the extent that they lead to the development of individuals' values (Gagné et al., 2010).

Masculinity is connected to work, a context where men feel specific pressure to prove themselves (Berdahl et al., 2018). Some organizations (e.g., police, firefighters, and the military), because they require work that historically demands masculine characteristics, are predominantly composed of men. In the case of police officers, masculinities are considered a means by which men can acquire resources that enable dominance over others (Berdahl et al., 2018). In the case of the military, men are the primary agents of propagating masculinities (Prokos and Padavic, 2002). This is reflected in domination through work and may be represented by the ability to secure social and head of household status (Berdahl et al., 2018).

In this context, over time, military police institutions create a collective order, where institutional symbols and gravitas compose the identity of the institution, tending to obscure the differences between the individuals that compose the military realm. However, they also create differences, as they shape and propagate an ideal of masculinity, associated with a conception of honor that identifies military police officers and their institutions (França, 2016).

As such, military police work is intrinsically associated with the ideal of masculinity (Carlson, 2019; Stuart and Benezra, 2018), as it can be considered a historical result of the creation of armies, which encouraged processes of disciplining and brutalization of the agents involved (França, 2016). Sometimes, in these contexts, individuals must reproduce masculinities to remain in the organization (Eccel and Grisci, 2011), even if they do not identify with these traits. These means can frustrate the individual in the organizational environment, when he does not find meaning in the activity developed that reproduces masculinities. Therefore, the question arises: what is the relationship between conceptions of masculinity and meanings of work for military police officers?

Based on the concept that organizational structures reflect masculinities that privilege the individuals who reproduce them (Eccel and Grisci, 2011; Fraga et al., 2020), the objective of this study was to analyze the relationship between conceptions of masculinity and the meanings of work for military police officers. The current studies on the meanings of work for military police officers are associated with the aspects of disability acquired in the undertaking of this work (Lopes and Leite, 2015), experiences of pleasure and suffering (Winter and Alf, 2019; Cunha and Ghizoni, 2018), and the risks of becoming ill at work (Ferreira et al., 2017). They also concern occupational stress (Santos et al., 2018), psychological wellbeing at work, distress and organizational commitment (Rodrigues et al., 2017). However, few studies relate the meaning of work with conceptions of masculinity in terms of the dimensions of meanings of work, especially for military police professionals.

One of the study's contributions was to show that organizations should rethink their Human Resources Management (HRM) policies and practices to ensure equality in the organizational sphere, allowing individuals to better identify with their work, thereby increasing the meaning of the work performed. It also showed how the 'macho' assumptions that individuals have in society are reflected in the organization and at work. Gender equality continues to require further maturation of policies and practices of HRM to balance the privileges of masculinities in organizations.

\section{Meanings of Work}

There are several contexts involving the meaning of work from a theoretical and epistemological perspective (Schweitzer et al., 2016). Victor Frankl, together with the studies of the MOW group, are the foundation for Estelle Morin's 
humanist-phenomenological work (Bendassolli and Borges-Andrade, 2011). According to the existentialist perspective, assigning meaning to one's own actions and those of one's society is a vital to the individual (Schweitzer et al., 2016). Therefore, the meaning of work is understood from the perspective of three dimensions (individual, organizational and social) (Morin, 2001) and six main characteristics (Table 1).

Table 1. Dimensions and antecedent constructs of the meanings of work.

\begin{tabular}{|c|c|c|}
\hline Dimensions & Characteristics & Examples \\
\hline \multirow{3}{*}{ Individual } & $\begin{array}{l}\text { Intrinsically satisfying (Morin, 2003; Morin, } \\
\text { 2001; Rodrigues et al., 2016; Bendassolli and } \\
\text { Borges-Andrade, 2011) or opportunity for } \\
\text { learning and development (Irigarayet al., 2017; } \\
\text { Bendassolli and Borges-Andrade, 2011). }\end{array}$ & $\begin{array}{l}\text { Solving problems, overcoming difficulties, exercising } \\
\text { creativity, in addition to the presence of feedback and } \\
\text { development mechanisms. }\end{array}$ \\
\hline & $\begin{array}{l}\text { Recognition (Rodrigues et al., 2016; Irigaray et } \\
\text { al., 2017). }\end{array}$ & $\begin{array}{l}\text { Having the respect and esteem of superiors and } \\
\text { colleagues, as well as being happy with support and } \\
\text { promotion prospects. }\end{array}$ \\
\hline & $\begin{array}{l}\text { It ensures safety and autonomy (Morin, 2003; } \\
\text { Morin, 2001; Rodrigues et al., 2016) or keeps one } \\
\text { busy (Morin, 2001). }\end{array}$ & $\begin{array}{l}\text { Being able to exercise their skills and solve } \\
\text { problems, make decisions about their work, besides } \\
\text { this being structured in routine, with a beginning, } \\
\text { middle and end, with a guarantee of adequate salary. }\end{array}$ \\
\hline Organizational & $\begin{array}{l}\text { Source of satisfying human relations experiences } \\
\text { (Morin, 2003; Morin, 2001; Rodrigues et al., } \\
\text { 2016) or cooperation and relationships among } \\
\text { colleagues (Irigarayet al., 2017) or is performed } \\
\text { efficiently and leads to an outcome (Morin, 2003; } \\
\text { Morin, 2001; Rodrigues et al., 2016). }\end{array}$ & $\begin{array}{l}\text { Doing work that enables one to have positive } \\
\text { relationships with colleagues. This contributes to the } \\
\text { development of the individuals' identity. }\end{array}$ \\
\hline \multirow[t]{2}{*}{ Social } & $\begin{array}{l}\text { Morally acceptable (Morin, 2001; Rodrigues et } \\
\text { al., 2017) or moral uprightness (Irigarayet al., } \\
\text { 2017). }\end{array}$ & $\begin{array}{l}\text { It contributes to society and is considered ethical and } \\
\text { morally acceptable, as well as respecting human } \\
\text { dignity and rights. }\end{array}$ \\
\hline & Social utility (Irigaray et al., 2017). & The work is useful to society. \\
\hline
\end{tabular}

Source: Authors (2021).

The first characteristic concerns an intrinsically satisfying work (Morin, 2001; Irigaray et al., 2017; Rodrigues et al., 2016; Bendassolli and Borges-Andrade, 2011) and one that provides opportunities for learning and development (Irigaray et al., 2017; Bendassolli and Borges-Andrade, 2011). Irigaray et al. (2017), when analyzing the meanings of work for criminal experts of the Federal Police, stated that, for these individuals, the meanings in their work are developed through opportunities for learning and development.

In relation to this characteristic, the meanings are also constructed when they generate sensations of pleasure with the work itself (Morin, 2001). The work provides opportunities for pleasure from the expression of values and the achievement of personal ambitions. Recent studies associated with the feeling of pleasure at work show that achievement and pleasure influence physical and emotional aspects, as well as the individual's perception of the meanings of work (Miorin et al., 2018; Primaria et al., 2015).

Meaningful work also allows for recognition (Morin, 2001; Rodrigues et al., 2016; Irigaray et al., 2017), which involves being recognized in the work environment, by customers (Morin, 2001; Nascimento et al., 2017), colleagues or superiors (Morin, 2001). Relationships also contribute to the development of people's identity (Morin, 2001) and knowledge transfer is a source of pleasure in the work environment associated with recognition (Calo, 2005).

The idea of developing satisfactory relationships is also found in the study of D'Arisbo et al.(2018) that dealt with higher education teachers from the public and private networks. The author showed that the substantive labor meanings, which involve the possibility of autonomy, development of satisfactory relationships, personal satisfaction, self-fulfillment, learning and development, feelings of attachment and of contribution to society, prevail over the instrumental meanings of work, which 
involve the financial return and the guarantee of survival.

Likewise, in relation to university teachers' work, the study of Irigaray et al. (2019) points to the identification of a new characteristic associated with teachers' current work: 'work as a calling'. This characteristic is related, in addition to morally acceptable work, to the fact that teachers view their work as a vocation, a calling to a higher and altruistic purpose (Irigaray et al., 2019). This characteristic is corroborate by Martela and Pessi (2018) who stated that meaningful work is based on the notion that it has to contribute to a greater good, something that extends beyond strictly individual benefits.

Regarding financial issues, when examining the meanings of work for Brazilians in management positions, the results of Bianchi (2018) point out that work is a means of obtaining financial resources, even when it is constituted as an activity that ensures satisfaction, a source of contact with other people and a way to be useful to society. Social utility is also pointed out in the studies of Morin (2001) and Irigaray et al. (2017).

Moreira Neto and Sachuk (2013) also concurred with these findings in their investigation of the meaning of work for inmates of the State Penitentiary of Maringá. For these individuals, work helps them to support their own families, in addition to being a means of re-socialization. It also represents a structuring and identity-forming factor for male prisoners (Moreira Neto and Sachuk, 2013). Similar results were found in a study on the meaning that prostitutes assign to work (Silva et al.,2013). The authors observed that the work performed, even though it is socially considered immoral, has meaning for them. In addition, the sex workers refer that their activity aims at survival and that of their families, besides representing a possibility of consuming what they want (Silva et al., 2013).

Studies on the meaning of work also show that it is related to efficiency and outcome (Morin, 2001; Bianchi, 2018; Irigaray et al., 2017; Rodrigues et al., 2017), social utility (Bianchi, 2018; Irigaray et al., 2017; Rodrigues et al., 2017) and intrinsic satisfaction (Bianchi, 2018; Rodrigues et al., 2017; D’Arisbo et al., 2018; Miorin et al., 2018; Primaria et al., 2015), as well as moral acceptance (Bianchi, 2018; D’Arisbo et al., 2018; Lopes, 2018; Morin, 2001; Rodrigues et al., 2017), occupation or routine (Morin, 2001), source of income (Bianchi, 2018; D’Arisbo et al., 2018; Morin, 2001; Rodrigues et al., 2017) and satisfying human relationships (Bianchi, 2018; Morin, 2001; Rodrigues et al., 2017).

\subsection{Masculinity}

The analysis of gender relations can be made based on the reflections of the historical-social relations between men and women, when addressed as phenomena of social constitution from issues related, for example, to beliefs, gender roles and values formed and shared (Pinto et al., 2007). Therefore, men and women are constituted based on the relationships established throughout their socialization process, i.e., the path taken from the moment of birth to adulthood, in the environments in which they are inserted (Guerra et al., 2014).

These processes of socialization of men are responsible for the constitution of several perceptions about their social roles and their meaning in society. These perceptions construct masculinities (Guerra et al., 2014). It is "a flexible concept, sustained by changeable social structures and norms, which follow historical, cultural and political changes" (Grossi, 2004 cited by Guerra et al., 2014, p. 73). Under this line of thought, it is possible to delve into masculinities, and the different conceptions thereof that involve several understandings of the meaning of being a man in society (Grossi, 2004). The ideas about masculinity indicate to men and women of a given society the accepted patterns of behavior, constituted and internalized in a cultural system of beliefs, based on the relationship between the sexes (O’Neil, 2012).

These beliefs shape men's behavior in a variety of ways. Therefore, as Guerra et al. (2014) state, men with greater internalization of traditional male stereotypes (e.g., strength, dominance, aggression, vast sexual experience) tend to exhibit risky sexual behaviors. These include casual sex, higher number of partners and a low rate of condom use (Murnen et al., 2002), grater alcohol consumption (Olmstead et al., 2013) and bullying and homophobic behaviors (Poteat et al., 2011). These 
also include sexual coercion and abuse of women (Manning et al., 2006), a lesser tendency to seek medical help in case of physical or mental illness (Galdas et al., 2005) and depressive symptoms (Syzdek and Addis, 2010), among others.

Oransky and Fisher (2009) sought to operationalize the construct of masculinity, proposing a measure capable of understanding its conceptions. These, updated from exploratory and confirmatory factor analyses in the Brazilian context (Guerra et al., 2014), are represented as: (1) emotional restriction in relation to the understanding that, to affirm their masculinity, men should not show emotions before others, hiding them, concealing emotional vulnerability; (2) heterosexism, i.e., the notion that masculinity is defined in opposition to femininity and homosexuality; therefore, men should not have 'feminine' or 'gay' behaviors and attitudes; and (3) social provocation, which refers to the hypothesis that, to ensure the affirmation of their masculinity, men should make jokes.

\section{Methodology}

This research is a quantitative survey, of descriptive and cross-sectional nature, using a technique of data collection involving a structured questionnaire. The choice of military police officers who participated in the research considered the nonprobability sampling process, since the sample was chosen by convenience.

To carry out this research, the questionnaire was designed based on studies on meanings of work, conceptions of masculinity and occupational characteristics of police officers. Hence, it has six blocks; block I addresses questions about the meaning of work and is composed of scale originally proposed by Morin and Cherré (1999) and validated by Morin (2003). Block II also addresses the meaning of work, but the questions were structured based on the categories emerging from the literature on police occupational characteristics (Benevides et al., 2014). To measure masculinity, we used the Masculinity Conceptions Scale, validated and adapted for the Brazilian context (Guerra et al., 2014) (Block III). Block IV contains questions that address the characterization of the participants (Table 2).

Table 2. Basis and structure of the instrument employed in data collection.

\begin{tabular}{|c|c|c|c|}
\hline \multicolumn{2}{|c|}{ Main Constructs } & Antecedent Constructs & Authors \\
\hline \multirow{6}{*}{$\begin{array}{l}\text { Meaning } \\
\text { s of work }\end{array}$} & \multirow{2}{*}{ Social Dimension } & Social Utility & \multirow{6}{*}{$\begin{array}{l}\text { Morin and Cherré (1999) and } \\
\text { Morin }(2003,2008) .\end{array}$} \\
\hline & & Moral Uprightness & \\
\hline & \multirow{3}{*}{ Individual dimension } & Opportunities for Learning and Development & \\
\hline & & Recognition & \\
\hline & & Autonomy & \\
\hline & Organizational dimension & Cooperation and Relationships with Colleagues & \\
\hline \multirow{3}{*}{\multicolumn{2}{|c|}{ Police occupational characteristics }} & Service to Society & \multirow{3}{*}{$\begin{array}{l}\text { Silvestri (2017), Paoline and } \\
\text { Terrill (2013), Bacon (2014) } \\
\text { and Atkinson (2016). }\end{array}$} \\
\hline & & Conservatism & \\
\hline & & Mission-action or Excitement & \\
\hline \multirow{3}{*}{\multicolumn{2}{|c|}{ Masculinity }} & Heterosexism & \multirow{3}{*}{ Guerra et al. (2014). } \\
\hline & & Emotional Restraint & \\
\hline & & Social Provocation & \\
\hline
\end{tabular}

Source: Authors (2021).

Data collection started with a preliminary test with five military police officers who belong to the group of respondents covered by the scope of the research. Three answered the printed instrument, and two answered the online instrument. The objective was to identify difficulties encountered by the respondents, evaluating the time required for completion, in addition to clarifying doubts regarding the instrument.

The online questionnaire link was sent via WhatsApp or the questionnaires were collected in person by the researchers. A total of 203 responses were received through online instruments and 177 responses by way of physical questionnaires, of which 127 and 170 respectively were used after duplicates were eliminated. Of the 297 participants, most of 
the sample was composed of males (76\%), who considered themselves as belonging to white ethnicity (88\%). Of the sample, $49 \%$ were between 26 to 35 years old and 27\% were between 36 to 45 years old. Most respondents were married (75\%) and had completed higher education (42\%). Regarding the level of education, incomplete higher education was the reality of $28 \%$ of the sample and completing high school education represented $20 \%$.

The data collected were tabulated and organized in a Microsoft Excel spreadsheet and then analyzed using JASP Statistics software (version 0.14.1). After the descriptive analyses were performed, the normality of the continuous variables was assessed using the Shapiro-Wilk test. As the data departed from the normal distribution, the Spearman correlation test was used (Table 3) to verify the relationship of the constructs of the Masculinity Conceptions Scale (heterosexism, social provocation and emotional restriction) with the dimensions of the meaning of work (social utility, learning and development opportunities, moral uprightness, cooperation and relationship with colleagues, recognition and autonomy). A 5\% significance level was used. 
Research, Society and Development, v. 10, n. 15, e79101522664, 2021

(CC BY 4.0) | ISSN 2525-3409 | DOI: http://dx.doi.org/10.33448/rsd-v10i15.22664

Table 3. Spearman's correlation between the variables studied.

\begin{tabular}{|c|c|c|c|c|c|c|c|c|c|c|c|c|}
\hline Variables & 1 & 2 & 3 & 4 & 5 & 6 & 7 & 8 & 9 & 10 & 11 & 12 \\
\hline 1. Social utility & -- & & & & & & & & & & & \\
\hline 2. Moral uprightness & $0.227 * * *$ & -- & & & & & & & & & & \\
\hline $\begin{array}{l}\text { 3. Opportunities for learning and } \\
\text { development }\end{array}$ & $0.218 * * *$ & $0.432 * * *$ & -- & & & & & & & & & \\
\hline 4. Recognition & 0.023 & $0.301 * * *$ & $\begin{array}{l}0.282 * \\
* *\end{array}$ & - & & & & & & & & \\
\hline 5. Autonomy & $0.134 * *$ & $0.429 * * *$ & $\begin{array}{l}0.440 * \\
* *\end{array}$ & $\begin{array}{l}0.480 * \\
* *\end{array}$ & -- & & & & & & & \\
\hline $\begin{array}{l}\text { 6. Cooperation and relationship } \\
\text { among colleagues }\end{array}$ & $0.257 * * *$ & $0.455 * * *$ & $\begin{array}{l}0.325^{*} \\
* *\end{array}$ & $\begin{array}{l}0.193^{*} \\
* *\end{array}$ & $0.370 * * *$ & -- & & & & & & \\
\hline 7. Service to society & $0.186 * * *$ & $0.317 * * *$ & $\begin{array}{l}0.204 * \\
* *\end{array}$ & $\begin{array}{l}0.172 * \\
* *\end{array}$ & $0.153 * * *$ & $\begin{array}{l}0.243 * \\
* *\end{array}$ & -- & & & & & \\
\hline 8. Mission-action or excitement & 0.028 & $0.094 *$ & 0.070 & -0.031 & 0.032 & $\begin{array}{l}0.186^{*} \\
* *\end{array}$ & 0.135 & -- & & & & \\
\hline 9. Conservatism & -0.003 & 0.040 & 0.054 & -0.020 & 0.063 & 0.066 & 0.065 & $\begin{array}{l}0.198^{*} \\
* *\end{array}$ & -- & & & \\
\hline 10. Heterosexism & 0.050 & 0.001 & -0.003 & 0.019 & 0.008 & 0.006 & -0.035 & $0.109 *$ & $\begin{array}{l}0.160 * \\
* *\end{array}$ & -- & & \\
\hline 11. Emotional restraint & -0.092 & -0.028 & 0.011 & -0.035 & -0.016 & -0.027 & -0.061 & $0.107 *$ & $\begin{array}{l}0.153 * \\
* *\end{array}$ & $\begin{array}{l}0.466^{*} \\
* *\end{array}$ & -- & \\
\hline 12. Social provocation & -0.022 & -0.059 & 0.024 & -0.044 & -0.027 & 0.058 & $-0.098 *$ & $\begin{array}{l}0.184 * \\
* *\end{array}$ & $0.098^{*}$ & $\begin{array}{l}0.313^{*} \\
* *\end{array}$ & $0.361 * * *$ & - \\
\hline
\end{tabular}




\section{Results and Discussion}

The results will be presented to allow discussion of the findings on the meanings of work and constructs of masculinities. For this, the following sections are organized into: (i) meanings of work; (ii) service to society; (iii) missionaction; (iv) conservatism; (v) heterosexism; (vi) moral constraint; and (vii) social provocation.

\subsection{Meanings of work}

In the present study military police officers were found to identify meaning in work with autonomy, moral uprightness and opportunities for learning and development. According to Isaksen (2000), autonomy represents experiences of empowerment and feelings of freedom, and is one of the ways to find meaning in work. The perception that it is possible to make decisions about tasks and time strengthens the experiences of consistency between individual and organizational values (Rodrigues et al., 2017).

The presence of autonomy as one of the main factors for the meaning of military police work differs from the results found in previous studies (Rodrigues et al., 2017). These indicate the military bureaucratic and hierarchical history, where obedience and attention to the order of roles and ranks are consolidated and unquestioned values that give meaning to the work. In this study, however, the questions about autonomy are related, in addition to the possibility of there being freedom at work, with the characteristics of doing it in a way aligned with one's own skills and interests. This is a likely explanation for the results pointed out.

Another important fact for the result attributed to autonomy in military police work is the hierarchy itself. On the one hand, if the bureaucratic and hierarchical history of the profession points to obedience and restriction of freedom (França and Gomes, 2015), the possibility of reaching higher positions may be a factor that allows for the formation of meanings of work and recognition. Therefore, autonomy can be seen as a possibility of growth within the organization (Winter and Alf, 2019), which fits in with the results of this study.

In addition, in this study, autonomy is directly related to recognition. The possibility of being recognized at work was also identified as an important factor for military police officers. In relation to recognition, the questions involved relationships with colleagues and superiors and the return on personal effort. Similarly, Rodrigues et al. (2017) state that recognition happens through respect and esteem from colleagues and superiors, or satisfaction with remuneration and working conditions. The result suggests that these aspects influence the perception of the meaning of work. The perception of recognition can be considered an indicator of motivation and generate impacts on productivity (Morin, 2001; Rodrigues et al., 2017).

The construct of moral uprightness presented significant relationships for the military police officers, leading to the conclusion that participants assign importance to working in a place that respects people and pays attention to dignity and human rights. Doing morally acceptable work through socially responsible activities, according to accepted standards (Morin, 2001), matches the bureaucratic background of the military profession (França, 2016).

The results of this study allow one to conclude that military police officers perceive that the meaning of work also comes from social utility. Military police officers identify value and importance in what they do because they produce important social impacts (Rodrigues et al., 2017). Social utility is related to performing useful work for others (Morin, 2001). Keyes (1998) ensures that, from the moment a police officer understands that his work is an important contribution to society, he considers himself someone valuable. Therefore, he establishes an identity process and strengthens his bond with the organization and work.

We can affirm that the study participants attribute value to what they do because they may also have access to professional opportunities. It is important to note that military police officers consider relevant the opportunities for the 
advancement of knowledge to generate benefits for the Brazilian society. The possibility of learning on the job is an important way to identify meaning in professional activity (Isaksen, 2000).

Work is also a decisive activity in social life because it puts people in contact with each other and contributes to the formation of social identity (Rodrigues et al., 2016). The present results showed a significant relationship between cooperation with colleagues and moral uprightness, indicated that military police officers consider that cooperation with colleagues is related to a moral issue, of respect for human dignity.

\subsection{Service to society}

Serving society reflects the values present in the police activity, representing a public ethos value (Rodrigues et al., 2017). In the present study, the results point to significant positive associations between this construct and the antecedents related to the meanings of work. Service to society is associated with all dimensions of the meanings of work (individual, organizational and social).

The association with this individual dimension of the meanings of work indicates that service to society is positively related to aspects of this dimension: the expression of personality, individuality and fulfilment of internal purposes (Martela and Pessi, 2018), intrinsic satisfaction (Morin, 2003; Morin, 2001; Rodrigues et al., 2016; Bendassolli and Borges-Andrade, 2011), recognition (Rodrigues et al., 2016; Irigaray et al., 2017). It is also associated with ensuring job security and autonomy (Morin, 2001, 2003; Rodrigues et al., 2016).

The significant positive relationships between the police occupational characteristic, being at the service of society, encompass the social dimension of the meanings of work. This construct is positively related to a job where there is moral uprightness (Irigaray et al., 2017) and that the job contributes positively to society (Morin, 2001; Rodrigues et al., 2017, Irigaray et al., 2017), and to the respect of dignity and human rights (Sampaio et al., 2019). In addition, performing work that serves society is positively associated with the constructs of the social dimension of meanings of work, which encompass labor that enables satisfying human relationships (Morin, 2001,2003; Rodrigues et al., 2016) or leads to an outcome (Morin, 2003; Morin, 2001; Rodrigues et al., 2016).

Despite the daily exposure to risky situations in the context in which they are inserted, this points to the importance of service to society in military police work. It is possible to perceive that the recognition of their work comes mostly from the construct of service to society. This is an indispensable element for maintaining the military police officers' sense of work.

\subsection{Mission-action or excitement}

Mission-action or excitement concerns the pleasure and adrenaline rush associated with 'catching the bad guy', as well as the quest for exciting realities. These activities are a common hallmark of police work (Campeau, 2015). This characteristic is identified for the study participants as they relate mission-action or excitement to two constructs of the meanings of work, cooperation and relationship with colleagues and service to society.

The positive association with cooperation and relationship with colleagues is in line with previous literature, which points to mission-action or excitement as being aligned with solidarity values (Campeau, 2015). This is a strong trend in the military police organization and represents a way to support group members by assuring mutual protection and defense when military personnel are confronted with external threats (Goldsmith, 1990).

Furthermore, the relationship with moral uprightness indicates that the spirit and adrenaline of 'catching the bad guy' may be associated with contemporary issues of respect for human dignity in our society. Especially in Brazil, issues related to human rights are emerging: "today, in a Democratic State of Law, there is no room for authoritarian practices, violent 
operations, that isolate popular participation in police activities and prioritize only repression" (Sampaio et al., 2019, p. 137).

Given the above, it is possible to consider that there are relationships of meaning between police and mission-action or excitement. But this is associated with solidarity among members of the group and with issues of dignity and respect for human rights, consequences of Brazilian historical and social evolution.

\subsection{Conservatism}

Conservatism is one of the occupational characteristics of police officers (Reiner, 2010), and can be exemplified in a police view that is intolerant towards changes in the status quo and does not accept changes in their work (Atkinson, 2016). This characteristic is related to compliance with rules, authority and hierarchy, traits of the military police (Reiner, 2010; França, 2016).

In relation to this study, the results show that conservatism is negatively associated with recognition and social utility. This association may indicate that police officers view the permanence to conservative rules (Azevedo, 2017), negatively associated with obtaining esteem from superiors and colleagues, a characteristic of the recognition construct (Rodrigues et al., 2016; Irigaray et al., 2017). Further research regarding these relationships is needed, as well as regards understanding why conservatism impacts perceived social utility.

\subsection{Heterosexism}

Heterosexuality is considered a basic characteristic in the hegemonic view of man (Bonomo et al., 2008). Therefore, some studies show that masculinity is affirmed in contradiction to femininity and homosexuality, defining what it is and is not to be a man (Bonomo et al., 2008; Oransky and Fisher, 2009). In relation to the findings of this research, the approval of heterosexist positions has no associations with the antecedent constructs of meaning of work but is associated with those of mission-action and conservatism. These results are consistent with the universe of military police training, where the ideal of masculinity and the militaristic culture predominate, historically legitimizing heterosexist civilizing principles (França, 2016).

Returning to the literature, it is possible to verify that, historically, for men to maintain status and be considered a Brazilian national citizen, it was necessary to have a life guided by marriage and constitution of a family (Miskolci, 2012). Based on this, when we observe the marital statuses of the participants of this study, $75 \%$ of the total individuals are married, underlining the relationship between conservatism and heterosexism.

In addition, previous studies show that discrimination against homosexuals has become an inherent condition of police culture (Reiner, 2010; Burke, 1992; França, 2016). From this perspective, the absence of associations between heterosexism and antecedent constructs of the meaning of military police work, as well as the average responses recorded for the construct, differ from those presented by previous studies (Burke, 1992; França, 2016). However, one of the hypotheses to try to explain this phenomenon would be to state that military police officers care about their image and that of the institution to which they belong: "in the PM [military police] profession, what is at stake is their image, which is also the institutional image" (França, 2016, p. 161).

Based on these considerations, the non-association between heterosexism and the constructs of meanings of work could be hypothetically understood as a protection of personal and organizational image. It may also be an indication of nonexpression of personal opinion, reinforcing the hierarchy of invisibility, which is typical of the profession (França, 2016). But we must be careful with this statement because negative associations were identified in relation to heterosexism and some constructs (learning opportunity, social utility and services to society). 


\subsection{Emotional restraint}

The expression of emotions can be a threat to masculinity, since the male stereotype is based on the ideas of virility and power (Bonomo et al., 2008). In this way, feminine characteristics, such as revealing one's own feelings, are a threat to the masculine identity (Guerra et al., 2014). The results of this study indicate negative associations of this conception with most of the antecedent constructs of work meaning. Although the repression of the emotional sphere is part of the traditional male identity, the lowest mean scores among the constructs of masculinity were attributed to this conception, according to the participants of this study.

The results also show the positive and significant association between emotional restriction and mission-action, conservatism and heterosexism. That is, the higher the emotional restriction, the greater the desire for the rules of the profession and homogeneity of heterosexism for police officers to be conserved. This non-association between emotional restriction and constructs of work meaning can be explained by the fact that emotional restriction consists not only of not revealing one's own feelings (Guerra et al., 2014), but also of not revealing one's own feelings to other men (Pimenta and Natividade, 2012). Since it is a predominantly male profession (Berdahl et al., 2018), other men represent many of the coworkers.

\subsection{Social provocation}

The results indicate a low association of social provocation with constructs of work meaning. But this dimension is associated with mission-action, heterosexism, and emotional constraint. The more police officers agree that they can mock or tease others, the more they agree with the items of arousal, heterosexism, and emotional constraint.

Social provocation refers to the assumption that for men to assert their masculinity, they must be able to tease or pick on their friends. And they also need to be able to resist such teasing when directed at themselves (Oransky and Fischer, 2009). Therefore, social provocation appears to have considerable importance for the affirmation of masculinity (Oransky and Fischer, 2009).

These results show that behaviors such as mocking friends relate to the excitement of the mission in action, the homogenization of heterosexism and emotional restriction. They also portray the idea of masculinity, where to be a virile and competent man, it is necessary to withstand provocation and teasing (Guerra et al., 2014; Oransky and Fischer, 2009). This idea is also related to the pedagogy of suffering, which is supported in military police courses, and "is related to the 'warrior ethos', which legitimizes the warmongering ideal emphasized by the institutional culture” (França and Gomes, 2015, p. 143).

\section{Conclusion}

The objective of this study was to analyze the relationship between conceptions of masculinity and meanings of work for military police officers. These professionals identify recognition in their work based on autonomy. In the military environment, this happens mainly within the hierarchical progression. It is also possible to affirm that recognition in the military police environment is related to the respect and esteem of colleagues and superiors. Military police officers also consider their work to have a strong relationship with moral uprightness and social utility, indicating that the meanings of work are associated with issues of dignity and respect for human rights and the feeling of generating impacts and results in society.

Regarding the conceptions of masculinity, the results show a homogenization of the individual in the organization under analysis: he cannot show emotions, must be heterosexual, endure provocation, and be conservative in relation to the values of the institution and profession. The discussions about masculinity can contribute to the awareness of military police officers, regardless of the hierarchical level, in relation to the cessation of possible spread of sexist ideals in military police 
organizations, which can limit the profile of individuals.

Despite the noticeable uncertainty about the importance of the masculinity debate in military police organizations, this is a possible alternative for the inclusion and permanence of homosexual professionals and women in these institutions. These organizational debates can contribute to strengthening the identity of publics who have historically struggled to be accepted in Brazilian society, especially in the military police environment and considered equal. From the perspective that organizations are part of society and that the social environment influences organizational outcomes, it is relevant to consider social aspects such as masculinity - when formulating policies and practices for HRM.

Considering the reflections of the meanings of work for individuals, organizations, and society, and taking into consideration the importance of military police work in contemporary society, this study has the managerial implication of disseminating knowledge to military police organizations. Whether these organizations are represented by regional bodies or other governmental spheres, they will be able to create mechanisms for valuing military police work based on the presentation of aspects of meanings of work. This study presents characteristics that can favor the recognition of these professionals, contributing to an increase in the meanings of work. This research can contribute to organizational strategies that encourage the permanence or attraction of professionals to this profession.

The study presents several limitations in the sample. Because it is a deliberately specific audience and, as seen above, has a high sense of protection of their own and organizational image, access to the sample was delicate. Due to these factors, it was impossible to get an equivalent number of participants according to gender. In addition, although different sociodemographic characteristics were considered, such as age, time of profession, marital status, state of residence, level of education, body to which they belong and color or race or ethnicity, there was no differentiation of these data in the analysis of the results, but only in the characterization of the sample of this study.

As suggestions for future studies, we recommend analyzing the importance of work in men's lives in present times and the significance of the meanings of work for public servants, whose professions directly impacts citizens and the state. Future studies can also investigate the reproduction of masculinities by women and homosexuals to remain in organizations and how this direction impacts their meanings of work. Additionally, including social issues such as color, race, ethnicity, and income may show different perspectives on masculinities.

\section{References}

Atkinson, C. (2016). Patriarchy, gender, infantilisation: A cultural account of police intelligence work in Scotland. Australian \& New Zealand journal of criminology, 50(2), 234-251. doi/abs/10.1177/0004865815626964.

Azevedo, E. F. D. (2017). A polícia e suas polícias: clientela, hierarquia, soldado e bandido. Psicologia: ciência e profissão, 37(3), 553-564. DOI:10.1590/1982-3703000192015

Bacon, M. (2014). Police Culture and the New Policing Context. In: Brown, J. (ed.), The Future of Policing. London: Routledge.

Bendassolli, P. F., \& Borges-Andrade, J. E. (2011). Significado do trabalho nas indústrias criativas. Revista de Administração de Empresas, 51(2), 143-159. https://doi.org/10.1590/s0034-75902011000200003

Benevides, T. M., Almeida, D. R. de, Cunha, E. A., \& Mendes, J. F. (2014). Sentidos Do Trabalho Para Os Policiais Militares Do Estado Da Bahia: Uma Primeira Análise Senses of Work for Military Police Officers in the State of Bahia : a First. Management and Connections Journal, 3(2), 181-197. https://doi.org/10.13071/regec.2317-5087.2014.3.2.8394.181-197

Berdahl, J. L., Cooper, M., Glick, P., Livingston, R. W., Williams, J. C. (2018). Work as a masculinity contest. Journal of Social Issues, 74(3), 422-448. https://doi.org/10.1111/josi.12289

Bianchi, E. M. P. G. (2018). Mean ing of Work fo r Man agers in the Braz ilian Contemporary Bu siness Context. RAM. Revista de Administração Mackenzie, 19(5). https://doi.org/10.1590/1678-6971/eramg180046

Bonomo, M., Barbosa, P. V., \& Trindade, Z. A. (2008). Homens: gênero e identidade em grupos tradicionais, metrossexuais e homossexuais no Brasil. Revista Electrónica de Psicología Política, 6(17), 1-22.

Burke, M. (1992). Cop Culture and Homosexuality. The Police Journal, 65(1), 30-39. https://doi.org/10.1177/0032258X9206500106 
Calo, T. J. (2005). The generativity track: A transitional approach to retirement. Public Personnel Management, 34(4), 301-312. https://doi.org/10.1177/009102600503400402

Campeau, H. (2015). "Police Culture" at Work: Making Sense of Police Oversight. British Journal of Criminology. British journal of criminology, 55(4), 669687. doi:10.1093/bjc/azu093

Carlson, J. (2019). Police Warriors and Police Guardians: Race, Masculinity, and the Construction of Gun Violence. Social Problems, 67(3), 399-417. https://doi.org/10.1093/socpro/spz020

Cunha, M. S. C., \& Ghizoni, L.D. (2018). Narrativas do sofrimento do trabalho de um policial militar afastado. Revista comunicação e inovação, 19(39), 132147.

D’Arisbo, A., Boff, D., Oltramari, A. P., \& Salvagni, J. (2018). Regime de flexibilização e sentidos do trabalho para professores em instituições públicas e privadas. Trabalho, Educação e Saúde, 16(2), 495-517. https://doi.org/10.1590/1981-7746-sol00125

Eccel, C. S., \& Grisci, C. L. I. (2011). Trabalho e Gênero: a produção de masculinidades na perspectiva de homens e mulheres. Cadernos EBAPE.BR, 9(1), $57-78$.

Ferreira, L. B., Santos, M. A. F., Paula, K. M. de, Mendonça, J. M. B., \& Carneiro, A. F. (2017). Riscos de adoecimento no trabalho entre policiais militares de um batalhão de Brasília. Gestão e sociedade, 11(29), 1804-1829. https://doi.org/10.21171/ges.v11i29.2150

Fraga, A. M., Antunes, E. D. D., \& Rocha-de-Oliveira, S. (2020). The female and the male professional: gender, career and expatriation interfaces in trajectory for female expatriates. Brazilian Business Review, 17(2), 192-210.

França, F. G. (2016). "Hierarquia da invisibilidade”: preconceito e homofobia na formação policial militar, Revista brasileira de segurança pública, 10(2), 154170 .

França, F. G., \& Gomes, J. L. F. (2015). "Se não aguentar, corra!”: Um estudo sobre a pedagogia do sofrimento em um curso policial militar. Revista brasileira de segurança pública, 9(2), 142-159.

Gagné, M., Forest, J., Gilbert, M., Aubé, C., Morin, E., \& Malorni, A. (2010). The motivation at work scale: Validation evidence in two languages. Educational and Psychological Measurement, 70(4), 628- 646. doi:10.1177/0013164409355698

Galdas, P. M., Cheater, F., \& Marshall, P. (2005). Men and health help-seeking behaviour. J Adv Nurs; 49(6): 616-623.

Goldsmith, A. (1990), 'Taking Police Culture Seriously: Police Discretion and the Limits of Law', Policing and Society, 1: 91-114. https://doi.org/10.1080/10439463.1990.9964608

Grossi, M. P. (2004). Masculinidades: uma revisão teórica. Antropologia em Primeira Mão, 75, 1-37.

Guerra, V. M., Scarpati, A. S., Duarte, C. N. B., Silva, C. V. da, \& Motta, T. A. (2014). Ser homem é...: adaptação da escala de concepções da masculinidade. Psico-USF, 19(1), 155-165. https://doi.org/10.1590/s1413-82712014000100015.

Hulin, C. L. (2014). Work and being: The meanings of work in contemporary society. In J. K. Ford, J. R. Hollenbeck, \& A. M. Ryan (Eds.), The nature of work: Advances in psychological theory, methods, and practice (pp. 9-33). Washington, DC, US: American Psychological Association.http://dx.doi.org/10.1037/14259-002

Irigaray, H. A. R., Barrichello, A., Morin, E. M., Rodrigues, A. L., \& Soares, D. R. (2017). O trabalho e seus sentidos: um estudo com peritos criminais da Polícia Federal. Revista de Administração Pública, 51(6), 1058-1084. https://doi.org/10.1590/0034-7612159318

Irigaray, H. A. R., Oliveira, L. B., Barbosa, E. S. T., \& Morin, E. M. (2019). Employment Relationships and Meaning of Work: a Research With Higher Education Professors. Revista de Administração Mackenzie, 20(1), 1-28. https://doi.org/10.1590/1678-6971/eramg190070

Isaksen, J. (2000). Constructing meaning despite the drudgery of repetitive work. Journal of Humanistic Psychology, 40(3), 84-107.

Keyes, C. L. M. (1998). Social well-being. Social Psychology Quarterly, 61(2), 121-140.

Lopes, E. M. de C., \& Leite, L. P. (2015). Deficiência Adquirida no Trabalho em Policiais Militares: Significados E Sentidos. Psicologia \& Sociedade, 27(3), 668-677. https://doi.org/10.1590/1807-03102015v27n3p668

Lopes, H. (2018). The mo ral dimen sions of the emplo yment relationship: institutional implications. Journal of Institutional Economics, 14(1), 103-125. https://doi.org/10.1017/s1744137417000170

Manning, W. D., Giordano, P. C., \& Longmore, M. A. (2006). Hooking Up: The Relationship Contexts of "Nonrelationship" Sex. Journal of Adolescent Research, 21(5), 459-483. https://doi.org/10.1177/0743558406291692

Martela, F., \& Pessi, A. B. (2018). Significant Work Is About Self-Realization and Broader Purpose: Defining the Key Dimensions of Meaningful Work. Frontiers in Psychology, 9, [363]. https://doi.org/10.3389/fpsyg.2018.00363

Miorin, J. D., Camponogara, S., Pinno, C., Beck, C. L. C., Costa, V., \& Freitas, E. de O. (2018). Prazer E Sofrimento De Trabalhadores De Enfermagem De Um Pronto-Socorro. Texto \& Contexto - Enfermagem, 27(2), 1-9. https://doi.org/10.1590/0104-070720180002350015

Miskolci, R. (2013). Machos e" Brothers": uma etnografia sobre o armário em relações homoeróticas masculinas criadas on-line. Estudos Feministas, 301-324. 
Moreira Neto, A. L. da C., \& Sachuk, M. I. (2013). Múltiplas Visões sobre as Atividades de Trabalho Remunerado, Desenvolvidas por Detentos na Penitenciária Estadual de Maringáentos na Penitenciária Estadual de Maringá. Gestão \& Regionalidade, 27(79). https://doi.org/10.13037/gr.vol27n79.1070

Morin, E. (2003). Sens Du Travail Sante Mentale Et Engagement Organisationnel Etude Morin.

Morin, E. M. (2001). Os sentidos do trabalho. Revista de Administração de Empresas, 41(3), 08-19. https://doi.org/10.1590/S0034-75902001000300002

Morin, E. M., \& Cherré, B. (1999). Les cadres face au sens du travail. Revue française de gestion, 83-95.

Murnen, S. K., Wright, C., \& Kaluzny, G. (2002). If "boys will be boys," then girls will be victims? Ameta-analytic review of the research that relates masculine ideology to sexual aggression. Sex Roles, 46(11-12), 359- 379.

Nascimento, R. L. do, Santos, A. S. L., \& Pinho, A. P. M. (2017). EnANPAD 2017 O Sentido do Trabalho para o Agente Funerário Autoria Raimunda Letícia do Nascimento EnANPAD 2017. (October).

Olmstead, S. B., Pasley, K., \& Finchman, F. D. (2013). Hooking up and penetrative hookups: Correlates that differentiate college men. Archives of Sexual Behavior, 42(1), 573-583

O'Neil, J. M. (2012). The Psychology of Men. In E. M. Altmaier \& J. C. Hansen (Eds.). The Oxford Handbook of Counselling Psychology (pp. 375-408). New York: Oxford University Press.

Oransky, M., \& Fisher, C. (2009). The Development and Validation of the Meanings of Adolescent Masculinity Scale. Psychology of Men \& Masculinity, 10(1), 57-72. https://doi.org/10.1037/a0013612

Paoline, E. A., \& Terrill, W. (2013). Police Culture: Adapting to the Strains of the Job.

Pimenta, S. M. de O., \& Natividade, C. (2012). Human, too Human: On emotions and masculinity. DELTA Documentacao de Estudos Em Linguistica Teorica e Aplicada, 28, 605-637. https://doi.org/10.1590/S0102-44502012000300009

Pinto, A. D. C., Meneghel, S. N., \& Marques, A. P. M. K. (2007). Acorda Raimundo! Homens discutindo violências e masculinidade. Rev. Psico. 38(3), 238245 .

Poteat, V. P., Kimmel, M. S., \& Wilchins, R. (2011). The moderating eggects of support for violence beliefs on masculine norms, aggression, and homophobic behavior during adolescence. Journal of Research on Adolescence, 21(2), 434-447. DOI: http://dx.doi.org/10.1111/j.1532-7795.2010.00682.x.

Primaria, A., Gabriela, L., Amaral, V., Teixeira, C. C., Afonso, T. C., Amaral, R. T., \& Bezerra, Q. (2015). O sentido do trabalho na Atenção Primária à Saúde The sense of work in Primary Health Care. 11(8), 1-8.

Prokos, A. \& Padavic, I. (2002). 'There Oughtta Be a Law Against Bitches': Masculinity Lessons in Police Academy Training. Gender, Work \& Organization. 9, 439-459. 10.1111/1468-0432.00168.

Reiner, R. (2010). The Politics of the Police. 4th edn. Oxford University Press.

Rodrigues, A. L., Barrichello, A., \& Morin, E. M. (2016). Os Sentidos Do Trabalho Para Profissionais De Enfermagem: Um Estudo Multimétodos. Revista de Administração de Empresas, 56(2), 192-208. https://doi.org/10.1590/S0034-759020160206

Rodrigues, A. L., Barrichello, A., Irigaray, H. A. R., Soares, D. R., \& Morin, E. M. (2017). Work and Its meanings: a study of forensic experts in the Federal Police. Revista de Administração Pública, 51(6), 1058-1084. https://doi.org/http://dx.doi.org/10.1590/0034-7612159318a

Sampaio, R., Eduardo, C., \& Silva, M. da (2019). Direitos humanos, atuação policial e sociedade civil. LIBERTAS: Revista De Ciênciais Sociais Aplicadas, $8(1), 135-140$.

Santos, M. J., Jesus, S. S., Tupinambá, M. R. B., Brito, W.F. (2018). Percepção de policiais militares em relação ao estresse ocupacional. Revista humanidades, 7(2).

Schweitzer, L., Gonçalves, J., Tolfo, S. da R., \& Silva, N. (2016). Bases epistemológicas sobre sentido(s) e significado(s) do trabalho em estudos nacionais. Revista Psicologia, Organizações e Trabalho, 16(1), 103-116. https://doi.org/10.17652/rpot/2016.1.680

Silva, K. A., Borges, G. F., Mafra, L. N. M., \& Cappelle, M. C. A. (2013). Ser Prostituta: o Sentido do Trabalho Moralmente Inaceitável. Revista Gestão Organizacional, 11(2), 215-246.

Silvestri, M. (2017). Police Culture and Gender: Revisiting the 'Cult of Masculinity', Policing: A Journal of Policy and Practice, 11(3), 289-300. https://doi.org/10.1093/police/paw052

Spinelli-de-Sá, J. G., \& Lemos, A. H. da C. (2018). Sentido do Trabalho: Análise da Produção Científica Brasileira. Revista ADM.MADE, 21(3), 21-39. https://doi.org/10.21714/2237-51392017v21n3p021039

Stuart, F., \& Benezra, A. (2018). Criminalized Masculinities: How Policing Shapes the Construction of Gender and Sexuality in Poor Black Communities. Social Problems, 65(2), 174-190. https://doi.org/10.1093/socpro/spx017

Syzdek, M. R., \& Addis, M. E. (2010). Adherence to masculine norms and attributional processes predict depressive symptoms in recently unemployed men. Cognitive Therapy Research, 34, 533-543.

Winter, L. E., \& Alf, A. M. (2019). A profissão do policial militar: vivências de prazer e sofrimento no trabalho. Revista Psicologia: Organizações e Trabalho, 19(3), 671-678. doi: 10.17652/rpot/2019.3.13214. 